\title{
Farms or freeways? Citizen engagement and municipal governance in Edmonton's food and agriculture strategy development
}

\author{
Mary A. Beckie, ${ }^{a} *$ University of Alberta

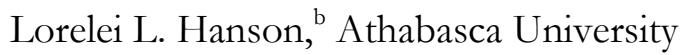 \\ Deborah Schrader, ${ }^{\mathrm{c}}$ University of Alberta
}

Submitted June 23, 2013 / Revised August 26 and October 4, 2013 / Accepted October 7, 2013 /

Published online November 30, 2013

Citation: Beckie, M. A., Hanson, L. L., \& Schrader, D. (2013). Farms or freeways? Citizen engagement and municipal governance in Edmonton's food and agriculture strategy development. Journal of Agriculture, Food Systems, and Community Development, 4(1), 15-31. http://dx.doi.org/10.5304/jafscd.2013.041.004

Copyright (C) 2013 by New Leaf Associates, Inc.

\section{Abstract}

In the mid- to late 1990s, most provincial governments in Canada downloaded or devolved

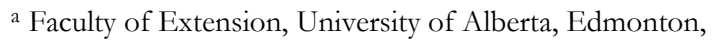
Alberta, Canada.

${ }^{\mathrm{b}}$ Faculty of Humanities and Social Sciences, Athabasca University, Athabasca, Alberta, Canada;

lorelei.hanson@athabascau.ca

${ }^{\mathrm{c}}$ Department of Educational Policy Studies, Faculty of Education, University of Alberta, Edmonton, Alberta, Canada; dschrade@ualberta.ca

* Corresponding author: Mary A. Beckie, Associate Professor, Faculty of Extension, University of Alberta; 10230 Jasper Avenue; Edmonton, Alberta, T5J 4P6 Canada; +1-780-4925153; mary.beckie@,ualberta.ca

Author note: The views and content presented in this paper are the sole responsibility of the authors. Some of the information contained in this paper was presented February 28, 2013, at the Saskatoon Food Summit II. The presentation can be accessed at http://www.usask.ca/foodsummit/2013/ presentations.php authority for land use planning to local levels of government. In Alberta, this shifted responsibility for the protection of farmland to municipalities. However, a strong oil and gas economy and rapid growth of Alberta's urban centers in recent decades has resulted in significant loss of prime farmland to urban and industrial development. In Edmonton, Alberta's capital city, citizens' concerns over food security and the protection of farmland within city boundaries shaped the 2010 municipal development plan, which links land use planning with food and agriculture, and also paved the way for an Edmonton agri-food strategy. In this exploratory case study we examine factors shaping Edmonton's food policy development and implementation, and the impact on prime farmland in the city's outer limits. Despite progressive changes in policy due to strong citizen support, municipal council's approval of a food and agriculture strategy lacking hard targets subsequently set the stage for continued urban sprawl and loss of prime farmland. This study illuminates the conflicts between 
citizens' demand for sustainable urban food systems and the development narrative still prevalent in many North American cities. We conclude the paper by discussing the key levers required to ensure the transformational context required to institute holistic food system strategies.

\section{Keywords}

citizen engagement, food policy, land use planning, municipal governance, urban agriculture, urban food and agriculture strategy

\section{Introduction and Methods}

In May 2010, Edmonton's city council approved a municipal development plan (MDP) that mandated the development of a Citywide Food and Agricultural Strategy (CWFAS) and required that future urban area structure plans be designed in adherence with this strategy (City of Edmonton, 2010a, p. 20). As a result, Edmonton became the first urban municipality in Canada to link land use planning with a comprehensive agriculture and food strategy, which was viewed as a major achievement by citizens advocating for local food system development. Extensive citizen engagement during the MDP process brought issues of food security and farmland preservation to Edmonton's municipal planning table, and generated unprecedented political attention. But as the process quickly unfolded, many became disillusioned by the level of commitment of senior administration and some members of city council to develop and implement a comprehensive, innovative, and robust strategy that would protect and utilize Edmonton's unique agricultural assets, including over 5,000 hectares $(12,355$ acres $)$ of prime farmland in the urban area.

This research utilizes an exploratory case study approach to examine food policy development in Edmonton from November 2008 to March 2013. All three authors undertook informal interviews and participant observations during a broad range of activities associated with food policy development. Beckie was a member of the CWFAS's advisory committee and in addition to attending 10 months of biweekly meetings in that role was able to observe a diversity of public and stakeholder consultation activities. Hanson and Schrader were academic researchers associated with the Food and
Agriculture Citizen Panel convened by a city/ university agency, the Centre for Public Involvement, and were also participants in activities and discussions organized by a civil society organization (Greater Edmonton Alliance (GEA)). Hanson is also a member of the city's Environmental Advisory Committee, a municipal advisory body that provided feedback on the process and documents associated with Edmonton's food and urban agriculture policy. Additional documents were reviewed including policy and background documents, meeting minutes, videos, and surveys, as well as handouts and e-mails written by citizens and more publicly accessible documents such as newspaper clippings and blog posts.

The theoretical framework for this interdisciplinary study was developed through a synthesis of readings on food systems, urban agriculture, food policy development, land use planning, citizen engagement, and governance related to sustainability. We drew from case research that examines successes and challenges in implementing crosssectoral food policies and strategies (Mansfield \& Mendes, 2013; Mendes, 2007, 2008; Sonnino, 2009), responded to the call for more comprehensive accounts of the evolution of food policy initiatives (MacRae, 1999; Mendes, 2007; Pothukuchi \& Kaufman, 1999, 2000; Wekerle, 2004), and aimed to contribute to scholarship on key levers required to move the food system to a more sustainable place (Meter, 2011). Specifically, we built on the work of Mansfield and Mendes (2013), who explore key structural and procedural factors that influence food policy development capacity (Mendes, 2008), and extended the analysis to account for additional procedural and contextual factors affecting Edmonton's food and agriculture strategy.

We begin with an overview of scholarship that explores citizen engagement with local food system development and sustainability issues in general, challenges of food policy work within the scope of municipal policy and planning, and the complexity of sustainability-related civic governance. The second section describes the development of fresh: Edmonton's Food and Agriculture Strategy (City of Edmonton, 2012a) and its related context. We conclude the paper by discussing the key levers 
required to ensure a transformational context for holistic food system strategies.

The Changing Nature of Citizen Engagement and Governance in Urban Food System Policy and Planning

Citizen involvement in municipal policy and decision-making has been a growing trend since the late 1960s, resulting in a "move away from expert-driven policy-making models towards processes that facilitate two-way information flow" and collaboration, in order to regain citizens' trust in government and to create "more robust, effective and equitable planning" (Masuda, McGee \& Garvin, 2008, p. 360; see also Healey, 2003; Innes, 1995). There is also growing recognition of the complexity and interconnectedness of the sustainability issues communities are grappling with, and the recognition that these cannot be solved by government alone (Calder \& Beckie, 2013; Cooper \& Vargas, 2004; Forrester, 2009; Innes \& Booher, 2004). Agriculture and food systems are "strategic considerations" in determining the sustainability of a municipality (Hiley, Bonneau, Thomas \& Rousseau, 2011, p. 27), and as Hassanein explains, "ultimately 'experts' cannot by themselves fairly make the decisions that impact the sustainability of agricultural production and the food system because those decisions involve choosing among values" (2003, p. 78). Tensions and conflict can arise, however, between individuals' values and the "good" of the community, and relations of power can influence the decision-making process regarding complex and polarized issues (Booher \& Innes, 2002; Healey, 2012; Mouffe, 2009). For example, governments might endorse engagement and yet provide limited opportunities and/or retain control over the process (McCann, 2001). Alternatively, engagement processes might be dominated by business and community elites or special interest groups (Rydin \& Pennington, 2000). Communities encompass multiple and diverse perspectives and "any substantial proposal for change is likely to generate all kinds of tensions and conflicts" (Healey, 2012, p. 20). To achieve inclusivity and collaboration in policy and planning "takes time, effort and resources" (Rydin \& Pennington, 2000, p. 161). Dialogue enabling multiple perspectives to be heard can lead to conflict but can also create a space for "new, more productive patterns" to emerge (Pearce \& Littlejohn, 1997, p. 79).

Municipal involvement and authority over agriculture and food has been increasing over the past two decades in both the Global North and South, in large part due to unprecedented urbanization pressures (Mansfield \& Mendes, 2013; Mougeot, 2006), citizen interest in localized food systems, and demand for supportive food and agriculture policy (Hiley et al., 2011; Morgan, 2013), and the devolution or downloading and offloading of responsibilities from higher levels of government (Hiley et al., 2011). Many municipal governments are beginning to acknowledge the "multifunctional nature" (Morgan \& Sonnino, 2010, p. 210) of urban agri-food systems; more than "just "feed the City"' (Sonnino, 2009, p. 426), they can also provide economic opportunities, skill training, social and cultural opportunities, and ecological functions (Beckie \& Bogdan, 2010; Evans \& Miewald, 2013; Mougeot, 2006; Thibert, 2012; Weissman, 2013).

The food policy response of local governments has varied and is influenced by a number of factors, including geography and climate, the economy, migration and settlement patterns, and cultural and political context (Schrader \& Hanson, 2012). In general, the number of targeted municipal policies (e.g., community gardens, small livestock, farmers' markets, community kitchens, food banks) has increased in North American cities in recent decades, but in many cases policies referring specifically to agricultural production are vague and open to differing interpretations (Desjardins, Lubczynski \& Xuereb, 2011; Oswald, 2009). City administrations may enthusiastically endorse urban agriculture if limited to community, rooftop, or backyard gardens, but view larger-scale agriculture enterprises as a regressive use of land when compared to residential development (Thibert, 2012), despite evidence of the higher long-term costs of infrastructure and services relative to agriculture (American Farmland Trust, 2010). Kaufman and Bailkey (2000) identify four types of obstacles to urban agriculture: site-related, government-related, procedure-related and perception-related. Given the long-term investment that agriculture requires, 
some scholars argue that the most significant obstacle is securing land tenure (Mubvami \& Mushamba, 2006); hence, there is a need for an integrated, systems approach that links land use planning with urban food policy (Desjardins et al., 2011; Hiley et al., 2011; Ikerd, 2011).

A small but growing number of cities have developed comprehensive, cross-sectoral food strategies (Sonnino, 2009), defined by Mansfield and Mendes (2013) as:

...an official plan or road map that helps City governments integrate a full spectrum of urban food system issues within a single policy framework that includes food production, food processing, food distribution, food access and food waste management. (p. 38)

Developing an urban agri-food strategy that integrates with other government policies (municipal, regional, provincial) and engages local stakeholders is complex and time-consuming work, and some authors question whether local governments have the supportive legislative framework, human and financial resources, and political will necessary to implement and integrate effective sustainability policies and programs of this nature (Barling, Lang, \& Caraher, 2002; Hiley et al., 2011; Mansfield \& Mendes, 2013; Mendes, 2008). Not only are municipalities stretched thin by continued funding cuts and the downloading of responsibilities from other levels of government, but also until very recently

\section{Table 1. Factors That Influence Governance Capacity for Food Policy Development}

\section{Structural issues \\ 1. Legal status and a mandated role for food policy; \\ 2. Staffing support; \\ 3. Integration of food policy into regulatory and legal frameworks; \\ Procedural issues \\ 4. Joint actor partnerships and networks in planning and policy making; and \\ 5. Citizen participation mechanisms.}

Source: Adapted from Mendes, W. (2008). Implementing social and environmental policies in cities: The case of food policy in Vancouver, Canada. International Journal of Urban and Regional Research, 32(4), 942-967. there have been "few policy roadmaps to follow or regulatory tools to support their implementation" (Mendes, 2008, p. 943). There is a degree of organizational learning and capacity-building that must occur across governmental institutions to be able to effectively implement a sustainable agrigovernance in support of sustainability goals requires structural, procedural and cultural changes to the institutions within which decisions are taken and actions carried out. In this regard, sustainability presents inherent challenges in relations to state resources, powers and capacity to act. (p. 944)

Key to the process of building institutional capacity is identifying mechanisms that both enable and limit effective collaborative local governance and policy development. In her analysis of the adoption of a food policy mandate in Vancouver, Mendes (2008) examined five key factors that influenced governance capacity to implement crosscutting social and environmental urban policy (table 1). These factors are both structural ("organizational arrangements and commitments involving governments") and procedural ("who is involved, when, how and where?”) (Mendes, 2008, p. 950). The partnerships and collaborations that emerge from the procedural elements help to address the cross-sectoral and multifaceted nature of urban food systems. We utilize the analytical framework developed by Mendes to examine the factors influencing urban food policy development in the city of Edmonton, Alberta.

\section{Description of the Case}

\section{Agricultural, Demographic and Legislative Context}

Alberta is one of the three Canadian Prairie provinces situated in the Northern Great Plains Region (figure 1). Close to one-third (31.5 percent) of 
Figure 1. Alberta's Location in Canada and North America

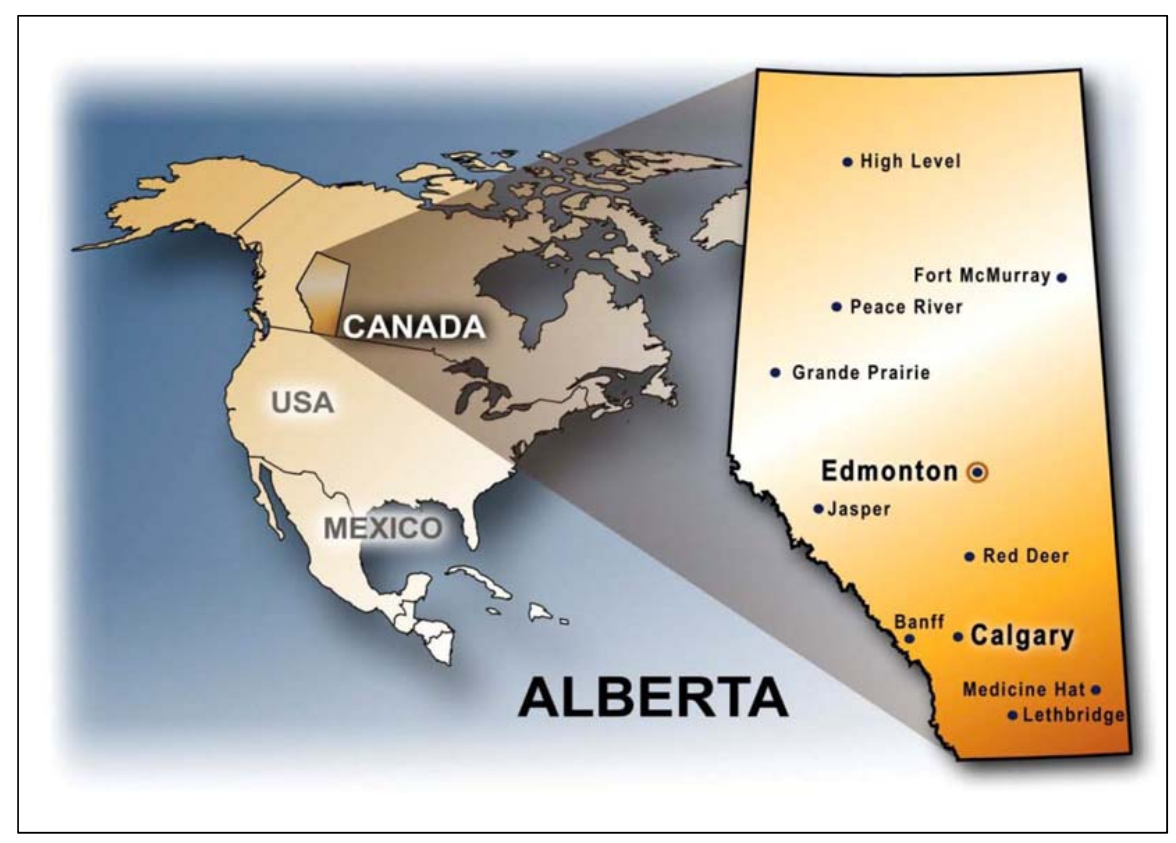

Source: Government of Alberta. (2011). Facts on Alberta: Living and doing business in Alberta. Edmonton, Alberta: Alberta Treasury Board.

the total amount of farmland in Canada ${ }^{1}$ and 18.97 percent of its Class 1 agricultural land ${ }^{2}$ is situated in Alberta (Statistics Canada, 2009), but changing demographics and strong economic growth in recent decades has resulted in an increasing loss of prime farmland in the province to urban residential, industrial, and commercial development, particularly in the rapidly urbanizing Calgary-toEdmonton corridor (Vander Ploeg, 2008), where most of the prime farmland in the province is located (Alberta Agriculture and Rural Development [AARD], 2002; Hofmann, Filoso, \& Shofield, 2005).

\footnotetext{
${ }^{1}$ In spite of Canada's relatively large size, only 7.3 percent of the land base (167 million acres) is utilizable for agricultural production, mainly because of soil quality and the nature of the Canadian climate and terrain (Statistics Canada, 2009).

2 There are seven classes used to rate agricultural land capability in Canada. Class 1 lands have the highest and Class 7 lands the lowest capability to support agricultural land use activities. Class 1 soils have no significant limitations in use for crops. Prime farmland is characterized as Class 1, 2, and 3. For further information see Agricultural Soil Classification, Canada Land Inventory, Agriculture and Agri-Food Canada: http://sis.agr.gc.ca/cansis/nsdb/cli/classdesc.html
}

Alberta's growth rate (10.8 percent) is nearly double the national average (5.9 percent), with 83 percent of the population of 3.65 million now living in urban centers (Statistics Canada, 2013b). From 2006 to 2011 the number of farms in the province declined by 12.5 percent and the amount of farmland decreased by 3.1 percent, or 647,497 hectares $(1,600,000$ acres), much of which consisted of high quality soils near urban centers (Statistics Canada, 2009). Land speculation and fragmentation of farmland due to urban and industrial development are also concerns as this drives up land prices beyond agricultural productivity values, making it financially difficult for farmers wanting to start or expand their operation while enticing others to sell their land, especially as they reach retirement age (AARD, 2002).

Land use planning is a provincial responsibility according to the Canadian Constitution (Government of Canada, 2013), but in the mid- to late 1990s authority over land use planning in many parts of the country was downloaded from provinces to municipalities and regions (Hiley et al., 2011). In 1994 the new Alberta Municipal Government Act abolished Regional Planning Commissions in the province and transferred responsibility for protecting agricultural land to municipalities (AARD, 2002). To aid this process, Provincial Land Use Policies were developed and municipalities are encouraged but not required to adhere to them (Alberta Urban Municipalities Association [AUMA], 2007). In contrast, British Columbia, Ontario, and Quebec have provincially legislated delineation of agricultural zones and urban growth boundaries (Hiley et al., 2011). In the prairies provinces, where approximately 80 percent of Canada's farmland is located, there is no legislation to 
protect this crucial resource (Acton \& Gregorich, 1995).

Alberta's provincial capital of Edmonton (pop. $812,201)$ has the second-highest population growth rate (12.1 percent) in Canada, next to Calgary (Statistics Canada, 2013a). Being a gateway to the oil sands and other industrial development in northern Alberta, as well as a major transportation link to the Canadian North, the entire Capital Region (Edmonton and 23 surrounding municipalities) has been characterized by strong growth for nearly two decades (Vander Ploeg, 2008). It is the northernmost census metropolitan area in Canada and occupies the largest land base $(11,993$ sq. $\mathrm{km}$ or 7,452 sq. miles) (Edmonton Capital Region Board, 2013). With a view to future growth, in 1982 Edmonton annexed approximately 8,000 hectares $(19,768$ acres) bordering the northeast, southeast and southwest parts of the city, and designated these as future Urban Growth Areas (UGAs) (figure 2). Much of this land was zoned agricultural and has mostly remained so over the past 30 years, making Edmonton one of the few urban municipalities in Canada with a large amount of prime agricultural land within its boundaries (HB Lanarc Consultants, 2012a). There have, however, been significant shifts in land tenure in the UGAs. Since the time of annexation the share of land owned by farmers has decreased by 43 percent; land leased and rented from land investment companies is now the predominant form of tenure (HB Lanarc Consultants, 2012a). There has

\section{Figure 2: Location of Edmonton and the Urban Growth Areas (Northeast, Southwest and Southeast) Within the Alberta Capital Region}

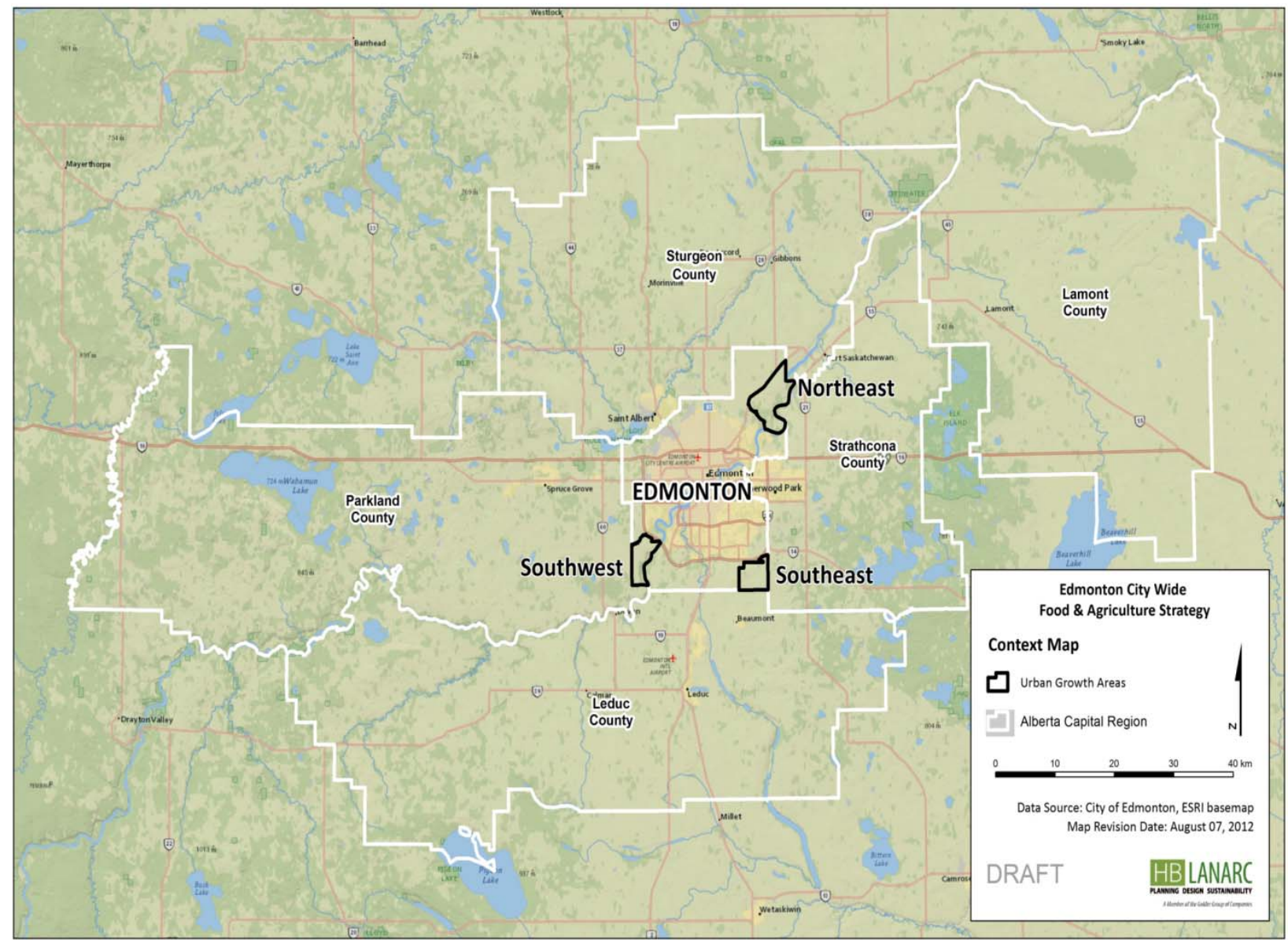

Source: HB Lanarc Consultants (2012a). Agricultural inventory \& assessment: City of Edmonton City Wide Food and Agriculture Strategy. Edmonton, Alberta: City of Edmonton. 
Table 2. Area, Soil and Climate Summary for Edmonton's Urban Growth Areas

\begin{tabular}{lccccc}
\hline Urban Growth Area & $\begin{array}{c}\text { Prime Agricul- } \\
\text { tural Soil (Class } \\
\text { Total Area } \\
\text { (Hectares) }\end{array}$ & $\begin{array}{c}\text { Prime Agricul- } \\
\text { tural Soil } \\
\text { (Hectares) }\end{array}$ & $\begin{array}{c}\text { Average Annual } \\
\text { Precipitation } \\
\text { (mm) }\end{array}$ & $\begin{array}{c}\text { Average Growing } \\
\text { Degree Days }\end{array}$ \\
\hline Northeast & 3,832 & 3,058 & $80.4 \%$ & 469 & 1,409 \\
\hline Southeast & 2,028 & 1,168 & $57.8 \%$ & 470 & 1,357 \\
\hline Southwest & 2,028 & 1,286 & $63.8 \%$ & 500 & 1,391 \\
\hline
\end{tabular}

Note: 1 hectare $=2.47$ acres; $500 \mathrm{~mm}=19.7^{\prime \prime}$

Source: HB Lanarc Consultants (2012a). Agricultural inventory \& assessment: City of Edmonton City Wide Food and Agriculture Strategy. Edmonton, Alberta: City of Edmonton.

also been a decline in the number of farms; for example, in the northeast UGA there was a 57 percent decrease in the number of farmers (from 170 to 73) from 2006 to 2011 (HB Lanarc Consultants, 2012a), in comparison to the provincial average of 13 percent during the same time period (Statistics Canada, 2009).

Seventy percent of Edmonton's UGAs is classified as prime agricultural land, consisting of Class 1, 2, and 3 soils (table 2). Approximately 50 percent of the northeast and southwest UGAs is Class 1 soils (HB Lanarc Consultants, 2012a). To put this in perspective, of the 7.3 percent of Canada's land mass suitable for agriculture, only 0.5 percent is Class 1 soils (Statistics Canada, 2009). The Edmonton area has additional qualities that make it well suited to crop production (HB Lanarc Consultants, 2012a). Despite its more northerly location, Edmonton has one of the longest growing seasons in Alberta. Moisture conditions in the Edmonton area are also better for crop production than more southerly parts of the province, where there is often a moisture deficit. This combination of favorable growing conditions is particularly evident in the northeast UGA, which has a combination of high quality soils, unique microclimate, and potential for irrigation due to its proximity to the North Saskatchewan River.

\section{The Way We Grow: Edmonton's Municipal Development Plan}

Every 10 years, Alberta municipalities with a population of 3,500 or greater are required to develop statutory municipal development plans
(MDP) (Alberta Municipal Affairs [AMA], 2012). Development of Edmonton's current MDP, titled The Way We Grow, began in 2006 and included an extensive public engagement process that included a project website, workshops, interviews, web and telephone surveys, and public and stakeholder consultations. The MDP underwent two reviews (in 2008 and 2009), with final approval in May 2010 (City of Edmonton, 2010a).

Most notable among those participating in the MDP process was a broad-based citizens' organization known as the Greater Edmonton Alliance (GEA). ${ }^{3}$ Through community meetings and social networking, GEA helped to mobilize over 500 citizens to attend the first MDP hearings in support of food and agriculture being included in the plan. GEA member institutions had identified food security and the preservation of prime farmland within city boundaries as key topics to be included in Edmonton's MDP (Nutter, Hubbard, \& Nutter, 2011). In response, Edmonton's city council requested that city administration staff research and report on possible urban food policy options and mechanisms to protect urban farmland (City of Edmonton, 2008).

GEA continued to educate and mobilize support for these issues among citizens, including

\footnotetext{
3 The Greater Edmonton Alliance (http://www.greater edmontonalliance.com) is a nonprofit, multi-issue network of civil society institutions such as faith-based organizations, business associations, unions, and community groups that work together to have an impact on community issues that matter to its member organizations.
} 
having more than 700 families pledge to shift 40 percent of their current food dollars to locally produced food (Nutter et al., 2011). In 2009, over 500 citizens again appeared at City Hall for the public hearing on the second draft of the MDP. GEA presented a policy paper, The $W$ ay $W e$ Eat, to city council and in it proposed amendments to the MDP related to agricultural land use and the development of a local food system (GEA, 2010). Councilors requested that these amendments be tabled for the next draft. That fall, GEA and a potato farmer situated in the northeast UGA hosted the "Great Potato Giveaway," an event that provided 45,000 kilograms ( 99,200 pounds) of potatoes free to the public as a means of inspiring people to come and experience a market garden, and also to raise awareness of the need to protect prime farmland in the area. Approximately 15,000 people participated in the one-day event, causing a massive traffic jam on the highway in northeast Edmonton (Drake \& Sands, 2009; Nutter et al., 2011). The event was viewed as highly successful in achieving its goals, as commented by Michael Walters, a GEA organizer:

We've [GEA] demonstrated the significant demand for local food, which was our intent. This land has more value than just being a holding pattern for urban growth. While the cities will continue to grow, we need to integrate agricultural land within that development. (Canadian Press, 2009)

As a result of extensive public input and support over two and a half years, in May 2010 more than 500 citizens witnessed city council's approval of the new MDP, which contained two amendments: Section 3.1: Land Use, and Section 5: Food and Agriculture. The former requires that future area structure plans be completed in alignment with the city's Growth Coordination Strategy, the Integrated Infrastructure Strategy, and a to-be-developed food and agriculture strategy (City of Edmonton, 2010a, p. 20). Hence, the UGAs' area structure plans could not be developed and approved before a local food and agriculture strategy was developed. Section 5 is a new addition to the MDP and provides a vision statement for the development of a comprehensive Citywide Food and Agriculture Strategy (CWFAS):

Edmonton has a resilient food and agriculture system that contributes to the local economy and the overall cultural, financial, social and environmental sustainability of the City. (City of Edmonton, 2010, p. 8)

\section{Development of Edmonton's Food and Urban Agriculture Strategy}

Edmonton City Council publicly launched Edmonton's food and urban agriculture initiative in May 2010, and that autumn the mayor appointed 15 individuals to serve on an advisory committee charged with developing a food and agriculture strategy. The CWFAS Advisory Committee consisted of a diverse set of stakeholders representing developers, land investment companies, international agricultural businesses, local nongovernmental organizations (NGOs), restaurants, postsecondary institutions, and local farmers (City of Edmonton, 2012b). ${ }^{4}$ Working with staff from Edmonton's Urban Planning and Environment Branch and HB Lanarc Consultants, ${ }^{5}$ the committee was tasked with guiding the development and completion of a strategy by spring 2012. The committee considered background documents developed by HB Lanarc Consultants, ${ }^{6}$ citizen feedback, and reviewed other municipal food strategies. The diversity of stakeholders on the committee gave rise to considerable and often polarized debate about various aspects of the strategy, with agricultural land preservation in the

\footnotetext{
${ }^{4}$ Absent from the advisory committee was representation from marginalized groups (immigrant, First Nations, low income), public health, K-12 education, and emergency food providers (food banks).

${ }^{5}$ HB Lanarc Consultants (http://www.hblanarc.ca) is a Vancouver-based planning and design firm that works with local and regional governments and developers on sustainable community and regional planning, and over the past decade has specialized in sustainable food-system strategies.

${ }^{6}$ Background documents developed by the consultants, such as the Agriculture Inventory and Assessment report, generated upto-date information that was valuable to the strategy development and will also be useful background information for implementation processes.
} 
Table 3. Citizen Engagement Processes Associated with the Development of Edmonton's Food and Urban Agriculture Strategy

\begin{tabular}{|c|c|c|c|}
\hline Type of Engagement & Frequency and Duration & Purpose and Output & $\begin{array}{c}\text { No. of } \\
\text { Participants* }\end{array}$ \\
\hline Advisory Committee & $\begin{array}{l}\text { Monthly, then biweekly, } \\
\text { meetings held Oct. } 2011- \\
\text { Sept. } 2012\end{array}$ & $\begin{array}{l}\text { - Create a draft citywide food and agriculture } \\
\text { strategy for Edmonton. } \\
\text { - A 94-page draft strategy written by a } \\
\text { professional writer in consultation with the } \\
\text { advisory committee. }\end{array}$ & 15 \\
\hline $\begin{array}{l}\text { Nine Key Stakeholder } \\
\text { Groups }\end{array}$ & $\begin{array}{l}\text { Two 3-hour meetings were } \\
\text { facilitated April-June } 2012\end{array}$ & $\begin{array}{l}\text { - Provide feedback on draft strategy components. } \\
\text { - Two summary reports produced by HB Lanarc } \\
\text { Consultants. }\end{array}$ & 120 \\
\hline Citizens Panel & $\begin{array}{l}\text { Six 4-hour facilitated } \\
\text { discussions held April-June } \\
2012\end{array}$ & $\begin{array}{l}\text { - Engage diverse citizens in discussions around } \\
\text { food and agriculture policy issues. } \\
\text { - The citizen panel produced a report with the } \\
\text { help of city staff and a professional writer. }\end{array}$ & 66 \\
\hline Public Conference & $\begin{array}{l}\text { Two-day conference with } \\
\text { invited local and national } \\
\text { speakers held in May } 2012\end{array}$ & $\begin{array}{l}\text { - Education and feedback on key food issues. } \\
\text { - Selected speaker videos were posted online. }\end{array}$ & 265 \\
\hline Public Opinion Survey & $\begin{array}{l}\text { Online and mailed surveys } \\
\text { administered in June } 2012\end{array}$ & $\begin{array}{l}\text { - Gather input for strategy. } \\
\text { - A report was written by the University of Alberta, } \\
\text { Evaluation \& Research Services. }\end{array}$ & 2,276 \\
\hline Landowner Survey & $\begin{array}{l}\text { Surveys mailed to } \\
\text { landowners in the UGAs in } \\
\text { June } 2012\end{array}$ & $\begin{array}{l}\text { - Understand current land use in UGAs and } \\
\text { landowners' future intentions for land. } \\
\text { - Summary report produced by HB Lanarc } \\
\text { Consultants. }\end{array}$ & 282 \\
\hline Open Houses & $\begin{array}{l}\text { Two open houses held for } \\
\text { invited stakeholders and } \\
\text { two held for the general } \\
\text { public, Oct. } 1-4,2012\end{array}$ & $\begin{array}{l}\text { - Feedback on draft version of strategy. } \\
\text { - Report produced by University of Alberta, } \\
\text { Evaluation \& Research Services. }\end{array}$ & 120 \\
\hline Online Survey & Oct. 1-4, 2012 & $\begin{array}{l}\text { - Feedback on draft version of strategy. } \\
\text { - Report produced by University of Alberta, } \\
\text { Evaluation \& Research Services }\end{array}$ & 205 \\
\hline
\end{tabular}

* Note: A number of people participated in multiple engagement activities.

Sources: Centre for Public Involvement, 2012; HB Lanarc Consultants, 2012b, 2012c, 2012d; University of Alberta, Evaluation \& Research Services, 2012a, 2012b.

UGAs being the most contentious. Although all members agreed that some of the prime farmland in the UGAs should be preserved, no consensus was reached as to how much land to preserve, where, and by what means.

A professional writer was hired to compose a draft of the strategy, with guidance from city staff. After many revisions submitted by committee members, a final draft of the strategy was presented to the committee and received mixed reviews; three members felt it was entirely unacceptable as it failed to align with the vision statement and did not set hard targets or goals, and four others felt it needed further revisions. With majority approval, the 94-page draft strategy was released to the wider community for review in October 2012, with a two-week period for submission of feedback through an online survey and four community open houses.

The city undertook a wide range of public consultation activities during the strategy development process (table 3). Prior to the final draft being approved, an online public opinion survey, a landowner survey, stakeholder meetings, a conference, and a citizen panel were convened. The city staff and consultants shared public feedback with the CWFAS Advisory Committee, but under very tight timelines for review and consideration. 
The citizen engagement processes revealed strong support for preserving prime farmland for agricultural production, particularly in the northeast UGA, and expanding urban agriculture in the city. The public opinion survey, completed by over 2,000 citizens, identified the availability of land to grow food for sale as a critical resource by 72 percent of respondents (University of Alberta, Evaluation \& Research Services, 2012a). Furthermore, 74 percent of participants identified locally grown or produced foods as an important factor influencing their food-buying decisions, and 54 percent stated that local ingredients were a key factor when deciding where to eat out. The highest rated recommendation of the randomly selected members of the citizens' panel was to "Create and/or amend zoning, bylaws, fees, and taxes to prohibit developments on good fertile agricultural land, particularly the northeast farmland" (Centre for Public Involvement, 2012, p. 2). The second highest recommendation was to "Maximize spaces and places within the City of Edmonton for urban growing and food production" (p. 2). Public feedback on the strategy revealed that more than 50 percent of the respondents ranked "Integrate land for agriculture" and "Expand urban agriculture" as their first, second or third priority (University of Alberta, Evaluation \& Research Services, 2012b).

On October 26, 2012, Edmonton's city administration presented the CWFAS to city council's executive committee for approval. A special nonstatutory public hearing was convened. Due to strong public interest, the hearings were extended over two days, during which 63 registered speakers were allowed to make five-minute presentations: 10 spoke for themselves, 53 represented a range of organizations including GEA, other NGOs, neighborhood organizations, the Edmonton Area Land Trust, landowners, real estate investors, and land developers (City of Edmonton, 2012a). The presentations represented primarily two positions: those opposed to having the strategy approved and those in favor. Those opposed to the strategy largely aligned with GEA, which had advocated for the protection of some portion of contiguous agriculturally zoned land in the area structure plans, ${ }^{7}$ felt that the wording of the CWFAS was not strong enough to ensure this could occur, and asked for more time to revise it. Those in favor of the strategy were composed largely of land investment company representatives, developers, and acreage landowners who spoke of the need for residential development and services to meet projected urban growth. Following the hearings, four out of five councillors voted in favor of accepting the draft strategy; the councillor opposed to the existing draft requested more data analysis, concrete recommendations, and targets. In response the executive committee asked that administration prepare an implementation plan and budget for the draft strategy.

Edmonton's food and urban agricultural strategy, titled fresh, received final approval November 2012, just thirteen months after the CWFAS Advisory Committee was first appointed. The strategy includes five goals that establish the foundation for an integrated food system, and nine strategic directions that provide a basis for action (table 4). Council also approved ongoing funding of CA $\$ 150,000$ per year to support one full-time staff person and the establishment and support of a food council to guide the implementation of the strategy.

With the approval of fresh, the northeast UGA area structure plan could now be prepared ${ }^{8}$ and presented to city council, which occurred in February 2013. Public hearings on the plan were held over two days. Forty-seven individuals spoke, many of whom had previously spoken at the strategy hearing (City of Edmonton, 2013a). Developers, land investors, and acreage owners in the northeast (including some farmers who had sold their land and were now renting it back) supported the plan, citing the need for housing and services for an adjacent 4,857 hectare (12,002 acre) energy and technology park that will be developed over the next 40 years (City of Edmonton, 2010b).

\footnotetext{
${ }^{7}$ GEA specifically requested 600 hectares (1,483 acres) of contiguous farmland bordering the North Saskatchewan River be protected in the northeast UGA.

${ }^{8}$ Unlike other most other urban municipalities in Canada, area structure plans in Edmonton are generated by developers, in consultation with local landowners and the city planning department.
} 


\section{Table 4. Goals and Strategic Directions of fresh: Edmonton's Food and Urban Agricultural Strategy}

\begin{tabular}{ll}
\hline \multicolumn{1}{c}{ Goals } & \multicolumn{1}{c}{ Strategic Directions } \\
\hline 1. A stronger, more vibrant local economy. & 1. Establish the Edmonton Food Council. \\
2. A healthier, more food-secure community. & 2. Provide food skill education and information. \\
3. Healthier ecosystems. & 3. Expand urban agriculture. \\
4. Less energy, emissions, and waste. & 4. Develop local food infrastructure and capacity. \\
5. More vibrant, attractive, and unique places. & 5. Grow local food supply and demand. \\
& 6. Enliven the public realm through diversity of food activities. \\
& 7. Treat food waste as a resource. \\
& 8. Support urban farmers and ecological approaches to farming. \\
\hline
\end{tabular}

Source: City of Edmonton. (2012b). fresh: Edmonton's food \& urban agriculture strategy. Retrieved from http://www.edmonton.ca/City government/documents/FRESH October 2012.pdf

Those opposed to the northeast area structure plan consisted mainly of citizens and GEA members, including the Northeast Edmonton Agricultural Producers (NEAP) who still own land and farm in the area; these presenters spoke about the need to preserve a larger and contiguous area of prime farmland in the northeast.

The northeast area structure plan, approved in June 2013 by Edmonton's city council in a vote of 10 to three, designates 200 hectares (494 acres) of privately owned but noncontiguous farmland, with a provincial highway shown as bisecting much of this. The plan also identifies the development of five neighborhoods (with a density of 31 units per hectare and an average housing price of CA $\$ 525,000)$, each of which requires more detailed neighborhood structure plans that will go to city council for review and approval (City of Edmonton, 2013c).

\section{Discussion}

This study indicates that Edmonton's Citywide Food and Agricultural Strategy development process addressed all the structural and procedural factors Mansfield and Mendes (2013) identify as key to municipalities effectively implementing a coordinated and integrated agri-food strategy. In response to strong citizen involvement with this issue, city council approved the integration of agriculture and food into the MDP, and thus created a statutory mandate for an agri-food strategy and also ensured future land use planning would have to consider and align with it. The city also dedicated a number of staff and significant financial resources ${ }^{9}$ to the strategy development process. Thus, the city met the three structural conditions Mansfield and Mendes identify as essential to providing an enabling institutional context for development of a progressive food policy. The city also addressed key procedural factors during the strategy development: first, by placing an array of community representatives on the CWFAS Advisory Committee, and second by providing a diverse range of opportunities for public and stakeholder consultation. These efforts to create inclusivity generated input from multiple perspectives for identifying goals and strategic directions that would "address the multi-jurisdictional and multi-sectoral nature of food systems" (Mansfield \& Mendes, 2013, p. 48).

Further analysis of this case, however, reveals additional procedural and contextual factors at play that are not accounted for in the framework presented by Mansfield and Mendes, but significantly influenced the content of the strategy and its implementation. To begin with, the development process was conducted over a relatively short period of time. Unlike other cities, such as Toronto or Vancouver, which developed food policies over a number of years, Edmonton's strategy process was allocated one year, despite repeated requests from a number of advisory committee members

\footnotetext{
${ }^{9}$ The total internal and external cost for the development of the CWFAS was CA $\$ 780,000$. The full report can be found in section 6.4, City of Edmonton Executive Council meeting minutes, at http://sirepub.edmonton.ca/sirepub/mtgviewer. aspx? meetid $=770 \&$ doctype $=$ MINUTES
} 
for more time to deliberate. Similarly, a number of presenters at the public hearing spoke of the need to grant more time to the process in order to create a robust strategy with targets and deadlines. The strategy includes "Expand urban agriculture" and "Integrate land for agriculture" as strategic directions, but protection of urban agricultural land is presented as part of a set of recommendations to consider, with no clear mandate or targets. Additionally, a cost-benefit analytical framework for different land-use scenarios is included in the strategy (City of Edmonton, 2012b), but several members of the advisory committee were dissatisfied with the final cost-benefit product and felt it was incomplete and needed to be tested before being released. Administration was intent on completing the strategy by the October 2012 deadline established by council, which they explained was necessary to secure budget funding for the implementation of the strategy. But another urgent motive was the concurrent development of the northeast area structure plan, which could not go forward for approval without the strategy in place.

Similar to many urban municipalities, community actors and agencies in Edmonton have played a key role in initiating food and agriculture activities and triggering related policy development. GEA was able to build upon community interest by educating and mobilizing a larger segment of the population in support of the development of urban agri-food policy. In response to strong citizen interest with this issue, the city incorporated extensive engagement opportunities through both representation on the advisory committee and a range of other citizen engagement activities. However, several studies have shown that inclusivity and dialogue do not guarantee democratic outcomes (e.g., Masuda et al., 2008, Rydin \& Pennington, 2000). Many citizens, GEA representatives and members of the advisory committee expressed feelings of frustration and cynicism about the engagement and collaborative efforts, as the strategy and the northeast area structure plan maintained the status quo. Two of the front-line planners involved said they felt demoralized and exhausted by the intense work schedule and unrealistic expectations placed on them. "We were swimming in data," said one of the planners in reference to the input that was gathered during the citizen engagement activities, but as a member of the advisory committee commented, there was not the time or the methods developed to effectively synthesize or incorporate the data into the decision-making process. In the end, many participants questioned the efficacy of public dialogue in changing policy outcomes in this complex and politically charged issue.

As a number of scholars of collaborative decision-making point out, conflict is both inevitable and productive in sorting through complex public policy issues (Booher \& Innes, 2002; Healey, 2012; Mendes, 2008). "Rather than taking conflict as a symptom of urban degeneracy, it instead can be understood as an asset of productive tensions that birth new possibility" (Mendes, 2008, p. 962). As the hearings for both the CWFAS and the northeast area structure plan revealed, the key disagreement focused on preserving a significant amount of contiguous prime farmland in the northeast UGA. At the hearing on the northeast UGA, GEA representatives commented that the condensed timeframe for the strategy greatly constrained the committee's discussions of different planning scenarios and economic development models, and thus prevented them from moving through disagreements to arrive at common ground. Some members of the advisory committee said they felt pulled into polarized positions, for or against the strategy, which undermined the opportunity for a thoughtful, richly innovative approach to creating an integrated urban landscape that could embrace the possible synergies and benefits of incorporating and preserving contiguous prime farmland within city boundaries. In this sense, the transformational learning and buy-in that are key to successful and innovative collaborative governance models were significantly constrained (Booher \&Innes, 2002; Bruff \& Wood, 2000).

The recent decisions that were made regarding Edmonton's municipal food and agriculture strategy and its implementation are embedded in historic events and a larger socio-political context. First, Edmonton's annexation of surrounding farmland in the 1980s for future urban growth triggered a number of changes, starting with a spike in land prices in Edmonton's UGAs shortly afterward due 
to land speculation (HB Lanarc Consultants, 2012a). High land prices combined with high interest rates during the 1980s influenced many farmers to sell their land to land investors and rent it back. Despite the agricultural potential of this land, it is not surprising that commitment to continue farming in an area designated for urban growth has declined, as evidenced by the dramatic reduction in the number of farms in the northeast from 2006 to 2011. As one scholar of urban and peri-urban agriculture has noted, "Given that agriculture generally requires long-term investment, land-use insecurity is especially problematic when trying to promote urban agriculture" (Thibert, 2012).

Second, new industrial and residential developments have been encroaching on the remaining urban farmland and in many ways predetermined the outcome related to Edmonton's northeast UGA. Perhaps of most significance is the adjacent energy and technology park, a cluster of secondary and tertiary chemical refining and manufacturing industries being built to support the oil and gas sector, which was approved in 2010 (City of Edmonton, 2013d). One of the key objectives for this park is to refine the byproducts produced by the oils sands and create additional refinery capacity (KlineGroup, 2008). The need for housing and services to support this technology park was cited as a critical factor supporting the approval of the northeast area structure plan.

Third, in Alberta there is no supportive legislative framework and coordination among different levels of government for preserving prime farmland, such as takes place in British Columbia, Quebec, and Ontario. When faced with growth and development pressures, many municipalities in Alberta have not followed provincial land use planning guidelines, explored policy options, or utilized tools, such as agricultural zoning, conservation easements, transfer of development credits, and urban growth boundaries, that could help address land use conflicts (Alberta Urban Municipalities Association [AUMA], 2007). In rural municipalities bordering major urban centers, there is a concern that "the agricultural voice is being overshadowed in municipal council chambers" (AARD, 2002, p. 4). According to Hiley et al. (2011), leadership and direction from the provincial level is a necessary condition for local government to effectively deal with this issue. Instead, the downloading of land use planning from provinces to municipalities, which has taken place in Alberta and throughout most of Canada, has not come with designated legislative authority or sufficient human and financial resources, and there has been a chronic lack of training opportunities for land use planning at the municipal level (Hiley et al., 2011). Unless these changes take place, tensions between citizens' demands for sustainable agri-food systems and loss of prime farmland due to urbanization will remain a controversial issue for municipalities.

\section{Conclusion}

Edmonton is in the early stages of implementing its agri-food strategy, and time will reveal how it will continue to unfold once the food council is underway (established summer 2013) and the new mayor and council (elected October 2013) begin to play a role in shaping this issue. What is clear, however, is that the level of citizen awareness and engagement with food and agriculture issues has increased significantly and that momentum will likely continue. Citizen involvement in food system planning is crucial, as "effective and acceptable local solutions require local decisions, which in turn require the extensive knowledge and participation of the people most affected by those decisions"

(Roseland, 2005, p. 222).

As municipalities across North America respond to growing citizen demand for sustainable agri-food systems, it is instructional to chart the evolution of urban policy development processes such as Edmonton's, identifying the factors that support capacity-building and enable cities to play a responsible and progressive role as food policy actors in an increasingly urbanized world. In the case study at hand, in many respects the procedural and structural mechanisms that enable crosscutting social and environmental policy were used. Yet as the hearings for the northeast area structure plan illustrated, despite strong public support for the protection of urban farmland, most members of city council were compelled to equate the value of this land according to short-term economic gains associated with urban residential develop- 
ment, despite the higher long-term costs of infrastructure and other services relative to agriculture, and the overall benefits of prime farmland preservation. Unable to adapt their view of development to include a more robust and integrated urban food system, Edmonton City Council approved a food and agricultural strategy that largely fits into the status quo of urban growth. Without a sufficient legislative framework and the designated authority to act therein, however, it is challenging for municipalities to address citizens' increasing demand to be bold and innovative in dealing with urban agriculture within the land use planning process. Hence this case study illustrates that instituting complex sustainability initiatives that have no clear jurisdictional home, such as is found in comprehensive municipal agri-food strategies, involves organizational learning and new governance arrangements if true urban transformation is to be achieved.

\section{Acknowledgements}

The authors would like to acknowledge and thank Jim Hiley, Candace Vanin, Monique Nutter, Debbie Hubbard, and the journal reviewers, editor, and managing editor for their valuable comments and suggestions for improvements to this paper. Some of the research that contributed to this paper was funded by Athabasca University and the Social Sciences and Humanities Research Council of Canada.

\section{References}

Acton, D. F., \& Gregorich, L. J. (Eds.). (1995). The bealth of our soils: Toward sustainable agriculture in Canada. Ottawa, Ontario: Centre for Land and Biological Resources Research, Research Branch, Agriculture and Agri-Food Canada. Retrieved from http://sis.agr.gc.ca/cansis/publications/manuals/ 1995-health/index.html

Alberta Agriculture and Rural Development [AARD]. (2002). Loss and fragmentation of farmland. Retrieved from http://www1.agric.gov.ab.ca/\$department/ deptdocs.nsf/all/psc4786

Alberta Municipal Affairs [AMA]. (2012). The legislative framework for regional and municipal planning, subdivision and development control. Retrieved from http://www.municipalaffairs.alberta.ca/ am planning and development.cfm
Alberta Urban Municipalities Association [AUMA]. (2007). Sustainable land use planning: Analysis and recommendations. Retrieved from http://www.ealt.ca/ media/uploads/Sustainable land use planning AUMA.pdf

American Farmland Trust. (2010). Cost of community services studies. Northampton, Massachusetts: Farmland Information Center. Retrieved from http://www.farmlandinfo.org/cost-communityservices-studies

Barling, D., Lang, T., \& Caraher, M. (2002). Joined-up food policy? The trials of governance, public policy and the food system. Social Policy \& Administration, 36(6), 556-574. http://dx.doi.org/10.1111/14679515.t01-1-00304

Beckie, M., \& Bogdan, E. (2010). Planting roots: Urban agriculture for senior immigrants. Journal of Agriculture, Food Systems and Community Development, 1(2), 77-89. http://dx.doi.org/10.5304/jafscd.2010.012.004

Booher, D. E., \& Innes, J. E. (2002). Network power in collaborative planning. Journal of Planning Education and Research, 21(3), 221-236. http://dx.doi.org/10.1177/0739456X0202100301

Bruff, G. E., \& Wood, A. P. (2000). Making sense of sustainable development: Politicians, professionals, and policies in local planning. Environment and Planning C: Government and Policy, 18(5), 593-607. http://dx.doi.org/10.1068/c9941

Calder, M. J., \& Beckie, M. A. (2013). Community engagement and transformation: Case studies in municipal sustainability planning from Alberta, Canada. Community Development, 44(2), 147-160. http://dx.doi.org/10.1080/15575330.2012.705868

Canadian Press. (2009, Sept. 26). Free spuds snarl Edmonton traffic. CBC News. Retrieved from http://www.cbc.ca/news/canada/edmonton/story /2009/09/26/edmonton-potato-give-away.html

Centre for Public Involvement. (2012). City-wide Food and Urban Agriculture Strategy: Report on citizen panel process and recommendations. Retrieved from http://www.edmonton.ca/City government/ documents/Food and Ag Strategy Citizen Panel Report Sept 2012.pdf

City of Edmonton. (2008, Nov. 12, 13). City council public hearing minutes. Retrieved from http://www.edmonton.ca/City government/coun cil committee meetings/archives-City-council2008.aspx 
City of Edmonton. (2009, June 23, 29). City council public hearing minutes. Retrieved from http://www.edmonton.ca/City government/ council committee meetings/archives-Citycouncil-2009.aspx

City of Edmonton. (2010a). The way we grow: Municipal development plan, bylaw 15100. Retrieved from http://www.edmonton.ca/City_government/ documents/MDP_Bylaw_15100.pdf

City of Edmonton. (2010b). Bylaw 15093: A bylaw to accept the Horsebills Energy and Techology Park Area Structure Plan. Retrieved from http://www.edmonton.ca/business economy/doc uments/Horsehills ASP Bylaw June 2010.pdf

City of Edmonton. (2012a). Special Executive Committee minutes, October 26, 2012 and November 2, 2012. Retrieved from http://sirepub.edmonton.ca/sirepub/mtgviewer. aspx?meetid $=1054 \&$ doctype $=$ MINUTES

City of Edmonton. (2012b). fresh: Edmonton's food \& urban agriculture strategy. Retrieved from http://www.edmonton.ca/City government/ documents/FRESH October 2012.pdf

City of Edmonton. (2013a, Feb 25, 26). City of Edmonton special city council public hearing minutes. Retrieved from http://sirepub.edmonton.ca/sirepub/mtgviewer. aspx?meetid $=1075 \&$ doctype $=$ MINUTES

City of Edmonton. (2013b, April 29). City of Edmonton Executive Committee meeting minutes. Retrieved from http://sirepub.edmonton.ca/sirepub/mtgviewer. aspx?meetid $=993 \&$ doctype $=$ MINUTES

City of Edmonton. (2013c). Community gardens. Environmental. Retrieved from http://www.edmonton.ca/environmental/conserva tion landscaping/community-gardens.aspx

City of Edmonton. (2013d). Horse Hill area structure plan receives preliminary council approval. Retrieved from http://www.edmonton.ca/City government/news L2013/horse-hill-area-structure-plan-receivespreliminary-council-approval.aspx

Cooper, P. J., \& Vargas, C. M. (2004). Implementing sustainable development: From global policy to local action. Lanham, Maryland: Rowman \& Littlefield.

Desjardins, E., Lubczynski, J., \& Xuereb, M. (2011). Incorporating policies for a healthy food system into land use planning: The case of Waterloo
Region, Canada. Journal of Agriculture, Food Systems, and Community Development, 2(1), 127-140. http://dx.doi.org/10.5304/jafscd.2011.021.003

Drake, L., \& Sands, A. (2009, September 27). Thousands dig in for free potatoes. Edmonton Journal. Retrieved from http://www.edmontonjournal. com/Thousands + free+potatoes/2038097/ story.html

Edmonton Capital Region Board. (2013). Alberta's Capital Region. Retrieved from http://capitalregionboard.ab.ca/

Evans, T. L., \& Miewald, C. (2013). Cultivating more than food: Where community gardens fit with what cities do. Journal of Agriculture, Food Systems, and Community Development, 3(2), 19-21. http://dx.doi.org/10.5304/jafscd.2013.032.013

Forrester, J. (2009). Improved partnership working for local authority transport planning. European Journal of Transport and Infrastructure Research, 9(3), 314-330. http://www.ejtir.tudelft.nl

Government of Alberta. (2011). Facts on Alberta: Living and doing business in Alberta. Edmonton, Alberta: Alberta Treasury Board. Retrieved from http://albertacanada.com/about-alberta/statisticsandpublications.html

Government of Canada. (2013). The Constitution Acts 1867 to 1982, Part VI, Section 92, Subject Matter Class 13. Ottawa, Ontario: Public Works and Government Services Canada.

Greater Edmonton Alliance [GEA]. (2010). The way we eat: Creating a vibrant and sustainable local food economy. Retrieved from http://greateredmontonalliance.com/wayweeat.pdf

Hassanein, N. (2003). Practicing food democracy: A pragmatic politics of transformation. Journal of Rural Studies, 19(1), 77-86. http://dx.doi.org/10.1016/S0743-0167(02)00041-4

HB Lanarc Consultants. (2012a). Agricultural inventory \& assessment: City of Edmonton City Wide Food and Agriculture Strategy. Edmonton, Alberta: City of Edmonton. Retrieved from http://landusekn.ca/ sites / default $/$ files $/ \mathrm{Ag}^{0} \% 20$ Inventory $\% 20$ and $\% 20$ Assessment $\% 20 \mathrm{Pt} \% 201 . \mathrm{pdf}$

HB Lanarc Consultants. (2012b). City-Wide Food and Urban Agriculture Strategy: Stakeholder groups feedback summary: Round one. Retrieved from http://www.edmonton.ca/City government/ documents/Food Ag Stakeholder Summary Round_1_Sept_2012.pdf 
HB Lanarc Consultants. (2012c). City-Wide Food and Urban Agriculture Strategy: Stakeholder groups feedback summary: Round two. Retrieved from http://www.edmonton.ca/City government/ documents/Food Ag Stakeholder Summary Round 2 Sept 2012.pdf

HB Lanarc Consultants. (2012d). City-Wide Food and Urban Agriculture Strategy: Landowner survey summary. Retrieved from http://www.edmonton.ca/City government/documents/Food and Ag Landown er Survey Summary Sept 2012.pdf

Healey, P. (2003). Collaborative planning in perspective. Planning Theory, 2(2), 101-123. http://dx.doi.org/10.1177/14730952030022002

Healey, P. (2012). Re-enchanting democracy as a mode of governance. Critical Policy Studies, 6(1), 19-39. http://dx.doi.org/10.1080/19460171.2012.659880

Hiley, J., Bonneau, G., Thomas, K., \& Rousseau, M. (2011). Canadian municipalities satisfy craving for sustainable agriculture and food systems. Municipal World, 121(4), 27-30.

Hofmann, N., Filoso, G., \& Schofield, M. (2005, January). The loss of dependable agricultural land in Canada. Rural and Small Town Canada Analysis Bulletin, 6(1). Ottawa, Ontario: Statistics Canada. Retrieved from http://www.statcan.gc.ca/pub/21006-x/21-006-x2005001-eng.pdf

Ikerd, J. (2011). Land use planning for sustainable food systems. Journal of Agriculture, Food Systems and Community Development, 2(1), 3-5. http://dx.doi.org/10.5304/jafscd.2011.021.010

Innes, J. (1995). Planning theory's emerging paradigm: Communicative action and interactive practice. Journal of Planning Education and Research, 14(3), 183189.

http://dx.doi.org/10.1177/0739456X9501400307

Innes, J. E., \& Booher, D. E. (2004). Reframing public participation: Strategies for the 21st century. Planning Theory \& Practice, 5 (4), 419-436. http://dx.doi.org/10.1080/1464935042000293170

Kaufman, J., \& Bailkey, M. (2000). Farming inside cities: Entrepreneurial urban agriculture in the U.S. [Working Paper]. Lincoln, Nebraska: Lincoln Institute of Land Policy. Retrieved from http://www.lincoln inst.edu/pubs/95 Farming-Inside-Cities

KlineGroup. (2008). From oil sands to a world-class eco-industrial chemical cluster for the greater Edmonton area: Final presentation overview version. Retrieved from http://www.edmonton.ca/ business economy/documents/Kline Study Eco Industrial Cluster-Overview.pdf

MacRae, R. (1999). Policy failure in the Canadian food system. In M. Koc, R. MacRae, L. J. A. Mougeot, \& J. Welsh (Eds.), For hunger-proof cities: Sustainable urban food systems (pp.182-194). Ottawa: International Development Research Centre. Retrieved from http://web.idrc.ca/openebooks/ 882-1/\#page 182

Mansfield, B., \& Mendes, W. (2013). Municipal food strategies and integrated approaches to urban agriculture: Exploring three cases from the global north. International Planning Studies, 18(1), 37-60. http://dx.doi.org/10.1080/13563475.2013.750942

Masuda, J. R., McGee, T. K., \& Garvin, T. D. (2008). Power, knowledge, and public engagement: Constructing "citizenship" in Alberta's industrial heartland. Journal of Environmental Policy \& Planning, 10(4), 359-380. http://dx.doi.org/10.1080/15239080802332026

McCann, E. J. (2001). Collaborative visioning or urban planning as therapy? The politics of public-private policy making. Professional Geographer, 53(2), 207-218. http://dx.doi.org/10.1111/0033-0124.00280

Mendes, W. (2007). Negotiating a place for "sustainability" policies in municipal planning and governance: The role of scalar discourses and practices. Space and Polity, 11(1), 95-119. http://dx.doi.org/10.1080/13562570701406683

Mendes, W. (2008). Implementing social and environmental policies in cities: The case of food policy in Vancouver, Canada. International Journal of Urban and Regional Research, 32(4), 942-967. http://dx.doi.org/10.1111/j.1468-2427.2008. 00814.x

Meter, K. (2011). Seventeen reasons to do food system assessments. Journal of Agriculture, Food Systems, and Community Development, 2(1), 7-10. http://dx.doi.org/10.5304/jafscd.2011.021.014

Morgan, K. (2013). The rise of urban food planning. International Planning Studies, 18(1), 1-4. http://dx.doi.org/10.1080/13563475.2012.752189

Morgan, K., \& Sonnino, R. (2010). The urban foodscape: World cities and the new food equation. Cambridge Journal of Regions, Economy and Society, 3(2), 209-224. http://dx.doi.org/10.1093/cjres/rsq007

Mouffe, C. (2009). The democratic paradox. London: Verso. 
Mougeot, L. J. A. (2006). Growing better cities: Urban agriculture for sustainable development. Ottawa: International Development Research Centre. Retrieved from http://www.idrc.ca/EN/Resources/ Publications/Pages/IDRCBookDetails.aspx? PublicationID $=327$

Mubvami, T., \& Mushamba, S. (2006). Integration of agriculture in urban land use planning and adaptation of city regulations. In R. van Veenhuizen (Ed.), Cities farming for the future: Urban agriculture for green and productive cities (pp. 53-86). Ottawa: International Development Research Centre Books. Retrieved from http://www.idrc.ca/EN/ Resources/Publications/Pages/IDRCBookDetails. aspx?PublicationID $=111$

Nutter, M., Hubbard, D., \& Nutter, B. (2011). Food security in Edmonton's municipal development plan. Calgary, Alberta: University of Calgary.

Oswald, J. (2009). Planning for urban agriculture. Plan Canada, 49(2), 35-38. http://www.cip-icu.ca/ web/la/en/pa/650FEC2824BE42928B524DD474 3A9B19/template.asp

Pearce, W. B., \& Littlejohn, S. W. (1997). Moral conflict: When social worlds collide. Thousand Oaks, California: SAGE.

Pothukuchi, K., \& Kaufman, J. L. (1999). Placing the food system on the urban agenda: The role of municipal institutions in food systems planning. Agriculture and Human Values, 16(2), 213-224. http://dx.doi.org/10.1023/A:1007558805953

Pothukuchi, K., \& Kaufman, J. L. (2000). The food system: A stranger to the planning field. Journal of the American Planning Association, 66 (2), 113-124. http://dx.doi.org/10.1080/01944360008976093

Roseland, M. (2005). Toward sustainable communities: Resources for citizens and their governments (Revised ed.). Gabriola Island, British Columbia: New Society.

Rydin, Y., \& Pennington, M. (2000). Public participation and local environmental planning: The collective action problem and the potential of social capital. Local Environment, 5(2), 153-169. http://dx.doi.org/10.1080/13549830050009328

Schrader, D., \& Hanson, L. L. (2012, November). City of Edmonton food and agriculture strategy: Setting the context.

Presentation at the Food Secure Canada Conference, Edmonton, Alberta.

Sonnino, R. (2009). Feeding the city: Towards a new research and planning agenda. International Planning
Studies, 14(4), 425-435.

http://dx.doi.org/10.1080/13563471003642795

Statistics Canada. (2009). Snapshot of Canadian agriculture. Retrieved from http://www.statcan.gc. ca/ca-ra2006/articles/snapshot-portrait-eng.htm

Statistics Canada. (2013a). The Canadian population in 2011: Population counts and growth (Catalogue no. 98-310-X2011001). Retrieved from http://www12.statcan.ca/census-recensement/ 2011/as-sa/98-310-x/98-310-x2011001-eng.cfm

Statistics Canada. (2013b). Focus on geography series, 2011 census: Province of Alberta. Retrieved from https://www12.statcan.gc.ca/censusrecensement/2011/as-sa/fogs-spg/Facts-preng.cfm? Lang $=$ eng\&GK $=P R \& G C=48$

Thibert, J. (2012). Making local planning work for urban agriculture in the North American context: A view from the ground. Journal of Planning Education and Research, 32(3), 349-357. http://dx.doi.org/10.1177/0739456X11431692

University of Alberta, Evaluation \& Research Services. (2012a). City-Wide Food and Urban Agriculture Strategy: Public opinion survey report. Retrieved from http://www.edmonton.ca/City government/ documents/Food and Ag Public Opinion Survey Report Sept 2012.pdf

University of Alberta, Evaluation \& Research Services. (2012b). fresh: Edmonton's Food and Urban Agriculture Strategy: fresh feedback survey report. Retrieved from http://www.edmonton.ca/City_government/ documents/FRESH Feedback Survey Report Oct 19 2012.pdf

Vander Ploeg, C. (2008). Big cities and the census: The growing importance of big cities and the demographic landscape. Calgary, Alberta: Canada West Foundation. Retrieved from http://cwf.ca/publications-1/bigcities-and-the-census-the-growing-importance-ofbig-cities-on-the-demographic-landscape

Weissman, E. (2013). No buts about it...The value of urban food production. Journal of Agriculture, Food Systems, and Community Development, 3(2), 23-24. http://dx.doi.org/10.5304/jafscd.2013.032.014

Wekerle, G. R. (2004). Food justice movements: Policy, planning, and networks. Journal of Planning Education and Research, 23(4), 378-386. http://dx.doi.org/10.1177/0739456X04264886 